\title{
ANDROGEN RECEPTOR EXPRESSION IN TRIPLE NEGATIVE BREAST CANCER AND ITS RELATIONSHIP TO PROGNOSTIC FACTORS
}

\author{
Expressão de receptor de androgênio em câncer de mama \\ triplo negativo e sua relação com fatores prognósticos
}

\begin{abstract}
Maximiliano Cassilha Kneubil*, Alessandra Eifler Guerra Godoy², Guilherme Portela Coelho³, Rafael Grochot', Renato Luis Rombaldi², Fábio Firmbach Pasqualotto², Bruno Wensing Raimann¹, José Mauro Madi², André Borba Reiriz², Mariana Alessi', Nathalia Hoffmann¹, Mariana Roesch-Ely², Janaína Brollo
\end{abstract}

\section{ABSTRACT}

Objective: Triple negative breast cancer (TNBC) is a subset of tumors with an aggressive intrinsic biology, resulting in poor prognosis. Androgen receptor (AR) is currently one of the most studied biomarkers in TNBC, playing a role in the genesis and development of breast cancer. Methods: In this cross-sectional study, we retrospectively reviewed the medical records of all patients with TNBC who received care from 2012 to 2014 at a single health center in southern Brazil. Histological material from breast tumors was analyzed by immunohistochemistry for AR expression and related to age, histological grade, tumor-infiltrating lymphocytes (TILs), and Ki-67. Results: Of 34 TNBC cases identified, 23 (67.6\%) were AR negative and 11 (32.4\%) were AR positive. The average age of the patients was 51.9 years (range: 30-82 years). Among positive cases, AR was weakly expressed in 6 and strongly expressed in 5 cases. Most patients $(n=28 ; 82.0 \%$ ) had poorly differentiated tumors. Mean Ki-67 expression was $65.0 \%$ in AR-negative and $43.6 \%$ in AR-positive cases $(p<0.05)$. There was a significant association between age and AR expression $(p<0.005)$, which was associated with mean age 70.8 years in the strongly AR-positive group and 42.3 years in the weakly AR-positive group. The mean percentage of TILs was 38.6\% in AR-positive and 39.1\% in AR-negative cases ( $p=0.391)$. Conclusion: There was no significant association between AR expression and histological grade or TILs. AR positivity in TNBC was associated with older age and tumors with lower Ki-67 expression, indicating two subgroups with distinct phenotypes in patients with TNBC.

KEYWORDS: Receptors, Androgen; Immunohistochemistry; Triple Negative Breast Neoplasms.

\section{RESUMO}

Objetivo: O câncer de mama negativo triplo (triple negative breast cancer - TNBC) é um subtipo de tumores com biologia intrínseca agressiva, resultando em pior prognóstico. O receptor de andrógeno (androgen receptor - AR) é atualmente um dos biomarcadores mais estudados em TNBC, desempenhando papel na gênese e no desenvolvimento do câncer de mama. Métodos: Neste estudo transversal, revisamos retrospectivamente os registros médicos de todos os pacientes com TNBC que receberam atendimento de 2012 a 2014 em um único centro no sul do Brasil. O material histológico dos tumores de mama foi analisado por imuno-histoquímica para a expressão de AR e relacionado a idade, grau histológico, linfócitos infiltrantes de tumores (TILs) e Ki-67. Resultados: Dos 34 casos identificados de TNBC, 23 (67,6\%) eram AR negativos e 11 (32,4\%), AR positivos. A idade média foi de 51,9 anos (30-82 anos). Entre os casos positivos, AR foi fracamente expresso em 6 e fortemente expresso em 5 casos. A maioria dos pacientes ( $n=28$, 82,0\%) apresentou tumores pouco diferenciados. A expressão média de Ki-67 foi de 65,0\% em AR-negativo e 43,6\% em AR-positivo $(p<0,05)$. Houve associação significativa entre a idade e a expressão de $A R(p<0,005)$, associada à idade média de 70,8 anos no grupo

Project performed at Biotechnology Institute, University of Caxias do Sul - Caxias do Sul (RS), Brazil and Diagnose - Laboratory of Pathology and Cytopathology - Caxias do Sul (RS), Brazil.

${ }^{1}$ Hospital Geral de Caxias do Sul - Caxias do Sul (RS), Brazil.

2Universidade de Caxias do Sul (UCS), - Caixas do Sul (RS), Brazil.

*Corresponding author: mcassilha@ig.com.br

Conflict of interests: nothing to declare.

Received in: 03/20/2017. Accepted in: 06/20/2017 
com AR fortemente positivo e de 42,3 anos no grupo com AR fracamente positivo. A porcentagem média de TILs foi de 38,6\% em AR-positivo e de $39,1 \%$ em AR-negativo ( $p=0,391)$. Não houve associação significativa entre expressão AR e grau histológico ou TILs. Conclusão: A positividade de AR em TNBC foi associada com idade mais avançada e tumores com menor expressão de Ki-67, indicando dois subgrupos com fenótipos distintos em pacientes com TNBC.

DESCRITORES: Receptores Androgênicos; Imuno-histoquímica; Câncer de Mama Triplo Negativo.

\section{INTRODUCTION}

Breast cancer is the most common malignancy among women in Brazil. Data from the Brazilian National Cancer Institute show that breast cancer accounted for 57,120 of 576,000 new cases of cancer diagnosed in 2014, being the most frequent tumor type in women (excluding non-melanoma skin cancer) ${ }^{1}$.

Triple negative breast cancer (TNBC) is a subset of tumors characterized by lack of expression of estrogen receptor (ER) and progesterone receptor (PR), as well as an absence of amplification or overexpression of human epidermal growth factor receptor 2 (HER2)/neu gene. TNBC accounts for approximately 15 to $20 \%$ of all breast tumors and is associated with aggressive biological behavior, increased risk of recurrence, distant metastasis, and poorer survival compared with hormone receptor-positive subtypes ${ }^{2-5}$. A panel of molecular alterations, such as increased rate of p53 mutations, elevated Ki-67 expression, loss of function of BRCA1, and presence of several tyrosine kinase activators, has been associated with this molecular subtype of breast cancer ${ }^{2}$.

Owing to the unfavorable biomolecular features of TNBC, conventional chemotherapy is the only treatment currently available for patients with this breast cancer subtype. Recent studies have attempted to identify biomarkers that allow us to subclassify these tumors into different prognostic groups and select patients who are candidates for more or less cytotoxic chemotherapy regimens, in addition to discovering new targeted therapies. Currently, androgen receptor $(\mathrm{AR})$ is one of the most extensively studied biomarkers in $\mathrm{TNBC}^{6}$.

$\mathrm{AR}$ is a protein localized in the nucleus of certain cells, where both testosterone and dihydrotestosterone bind to the AR. This receptor is normally found in the male urogenital system and in areas where hair usually grows in men. Recent studies, however, have also demonstrated its expression in breast cancer, including TNBC. According to Collins et al.7, 77\% of invasive breast carcinomas are AR positive. In addition, AR expression was commonly observed in luminal A (91\%) and B (68\%) tumors, but was less frequently observed in HER2/neu positive subtypes (59\%). Although TNBC is defined by absence of ER and PR expression and is considered hormonally unresponsive, $35 \%$ of TNBC express $\mathrm{AR}^{8}$. However, the actual role of AR expression as a prognostic factor in TNBC remains unclear.

The current study was therefore designed to evaluate $\mathrm{AR}$ expression by means of immunohistochemistry in all TNBC cases recorded at a single health center in Southern Brazil from 2012 to 2014 and relate AR expression to prognostic factors obtained from clinical and pathological reports.

\section{METHODS}

We conducted a cross-sectional study with medical record review of breast cancer patients who received care from January 2012 to June 2014 at a single health center located in Caxias do Sul, a city in Southern Brazil. The study was approved by the Research Ethics Committee of Hospital Virvi Ramos (protocol no. 383,616). Informed consent was waived due to the noninterventional design of the study and retrospective nature of data collection.

Data were collected from electronic medical records completed during the histopathological evaluation of biopsies and/or surgical specimens obtained at Diagnosis Laboratory of Pathology and Cytopathology. We retrospectively identified all patients with a main diagnosis of invasive carcinoma of no special type (NST), according to the 4th edition of the World Health Organization (WHO) Classification of Tumors of the Breast, published in 2012, or invasive ductal carcinoma not otherwise specified (NOS), according to the 3rd edition, published in $2003^{9}$.

Eligible participants were all women with a diagnosis of invasive ductal carcinoma NOS or invasive carcinoma NST with triple negative phenotype (TNBC). Medical records with incomplete or missing information on clinical and pathological parameters required for analysis were excluded.

The histological material from patients with TNBC was analyzed by immunohistochemistry for AR expression and related to the following clinical and pathological parameters: patient age, histological tumor grade, tumor-infiltrating lymphocytes (TILs), and Ki-67.

\section{IMMUNOHISTOCHEMISTRY}

In all selected TNBC cases, immunohistochemical staining was performed for AR, ER, PR, HER2, and Ki-67 on 3- $\mu$ m tissue sections cut from the original paraffin blocks. Sections were first deparaffinized and antigen retrieved. For each marker, immunostaining was performed on an automated immunostainer 
(Autostainer Link 48; Dako Corp., Carpinteria, CA, USA) using a multiple-step staining procedure.

The following monoclonal antibodies were used: mouse antihuman AR (1:50, clone AR441, Dako); ER (1:100, clone PPG5/10, Dako); PR (1:800, clone PgR 636, Dako); and a monoclonal antibody for Ki-67 antigen (1:2000, clone MIB-1, Immunotech, Marseille, France). It was also used the polyclonal antiserum with HER2 protein for HER2/neu gene (clone SP3, Spring).

\section{SCORING SYSTEM}

Staining results were assessed independently by two pathologists. AR staining was classified using the $\mathrm{H}$-score ${ }^{10}$, which ranges from 0 to 300 and is calculated according to the following formula: $(1 \times$ percentage of cells staining weakly positive) $+(2 \times$ percentage of cells staining moderately positive $)+(3 \times$ percentage of cells staining strongly positive). H-score $\leq 150$ was considered weak AR expression and $\mathrm{H}$-score $>150$ was considered strong AR expression.

ER and PR were considered positive if $\geq 1 \%$ of tumor cells stained positive, as recommended by the American Society of Clinical Oncology/College of American Pathologists (ASCO/ CAP) ${ }^{11}$.

HER2 staining was assessed using a semiquantitative score ranging from 0 to $3+$, where 0 or $1+$ indicate a negative, $2+$ indicates an indeterminate, and $3+$ indicates a positive HER 2 test result (Table 1$)^{12}$. All cases with $2+$ staining underwent fluorescence in situ hybridization (FISH) for evaluation of HER2 gene amplification, as recommended by ASCO/CAP. The FISH assay was performed using dual red and green DNA probes corresponding to HER2 and chromosome 17 centromere (CEN17), respectively. HER2 was considered amplified when the HER2/CEN17 ratio was $\geq 2.2$, according to ASCO/ CAP guidelines ${ }^{12}$.

For Ki-67 analyses, immunostaining was performed on an automated immunostainer (Autostainer Link 48; Dako Corp., Carpinteria, CA, USA) using a multiple-step staining procedure and a specific monoclonal antibody for Ki-67 antigen (clone MIB1, dilution 1:2000, Immunotech, Marseille, France). The Ki-67 expression levels were expressed as the percentage of cells with positive nuclear staining among the total number of tumor cells (at least 1,000 were counted) ${ }^{13}$. For ki-67, a higher cutoff point (50\%) was used because $70 \%$ of TNBC cases showed Ki-67 labeling indices $>50 \%$.

The percentage of TILs was assessed in paraffin-embedded tumor sections stained with hematoxylin and eosin (HE) and was defined as the percentage of lymphocytes in direct contact with tumor cells ${ }^{14}$.

All cases were graded according to the WHO histopathological classification ${ }^{15}$ as well-differentiated (grade 1), moderately differentiated (grade 2), or poorly differentiated (grade 3$)^{9}$.

\section{STATISTICAL ANALYSIS}

Continuous variables were expressed as standard deviation (SD) and analyzed using Student's $t$-test. Categorical variables were expressed as absolute and relative frequencies and analyzed using the $\chi^{2}$ test with $95 \%$ confidence interval $(95 \% \mathrm{CI})$. Data analysis was performed using SPSS, version 17.0. The level of significance was set at $5 \%(p<0.05)$.

Table 1. Relationship between androgen receptor expression and age in patients with triple negative breast cancer.

\begin{tabular}{|c|c|c|c|c|c|}
\hline \multirow{3}{*}{ Variable } & \multicolumn{4}{|c|}{ Androgen receptor expression } & \multirow{3}{*}{ p-value } \\
\hline & \multicolumn{2}{|c|}{ Positive (n=11) } & \multicolumn{2}{|c|}{ Negative $(n=23)$} & \\
\hline & $\mathbf{n}$ & $\%$ & $n$ & $\%$ & \\
\hline Age (years) & & & & & 0.038 \\
\hline $30-34$ & 3 & 27.3 & 2 & 8.7 & \\
\hline $35-39$ & - & - & 5 & 21.7 & \\
\hline $40-44$ & - & - & 2 & 8.7 & \\
\hline $45-49$ & - & - & 3 & 13.0 & \\
\hline $50-54$ & 2 & 18.2 & 4 & 17.4 & \\
\hline $55-59$ & 2 & 18.2 & 1 & 4.3 & \\
\hline $60-64$ & 1 & 9.1 & - & - & \\
\hline $65-69$ & - & - & 3 & 13.0 & \\
\hline$>70$ & 3 & 27.3 & 3 & 13.0 & \\
\hline Mean $\pm S D$ & $55.3 \pm 18.7$ & & $50.5 \pm 13.7$ & & NS \\
\hline
\end{tabular}

NS: not statistically significant; SD: standard deviation; p-values $<0.05$ were considered significant. 


\section{RESULTS}

Among 314 patients with invasive breast carcinoma who received care at our institution from January 2012 to June 2014, 34 had TNBC (10.8\%) and were included in the analysis. Of these, diagnosis was obtained for 24 patients from percutaneous biopsies and for 10 patients from surgical specimens. There were no exclusions.

The mean age of patients with TNBC was 51.9 years (SD: 15.36 years; range: 30 to 82 years). Of 34 TNBC cases identified, $23(67.6 \%)$ were AR negative and 11 (32.4\%) were AR positive. Among positive cases, AR was weakly expressed (H-score $\leq 150)$ in 6 cases and strongly expressed (H-score $>150)$ in 5 cases. Most tumors showed high Ki-67 expression, with labeling indices above $50 \%$ in 18 of 34 cases (52.9\%). A high histological grade was observed in all cases, with $28(82.0 \%)$ tumors graded as poorly differentiated (G3) and 6 (18.0\%) as moderately differentiated (G2).

The results of the relationship between AR expression and age in patients with TNBC are shown in Table 1. AR-positive patients were older (mean age: $\mathbf{5 5 . 3}$ years) than AR-negative patients (mean age: 50.5 years), but with no significant difference between groups. Specifically among AR-positive patients, $72.8 \%$ ( $8 / 11$ cases) were older than 50 years $(p=0.038)$.

The results of the relationship between AR expression and Ki-67, histological grade, and TILs in patients with TNBC are shown in Table 2 . There was a statistically significant association between AR-positive cases and Ki-67 antigen expression $<50 \%(p<0.038)$. In both AR-positive and AR-negative tumors, the histopathological grading was predominantly G3 $(p=0.309)$. The mean percentage of TILs was $38.6 \%$ in AR-positive cases and $39.1 \%$ in AR-negative cases $(p=0.391)$. There was no statistically significant association between AR expression and histological grade or TILs.

In the strongly AR-positive group (H-score $>150)$, all patients were older than 50 years, and this variable was significantly associated with the mean age 70.8 years $(p<0.003)$ (Table 3$)$.

The mean values for Ki-67 expression, percentage of histological grade G3 and percentage of TILs, although higher in the weakly AR-positive group, did not reach statistical significance (Table 4).

\section{DISCUSSION}

In the present series, the prevalence of TNBC expressing AR was $32.3 \%$, a rate similar to the mean rates reported in previous studies, ranging from 32 to $35 \%^{7,8}$. These data reinforce the importance of studying AR in breast cancer, since a significant number of patients with TNBC, in the near future, might benefit from new targeted therapies.

AR signaling exerts an anti-estrogenic effect, inhibiting cell proliferation in normal breast tissue, and this action is more evident in luminal breast cancer, in which the concomitant expression of estrogen receptor- $\alpha[\mathrm{ER} \alpha)$ and $\mathrm{AR}$ is associated with a favorable prognosis ${ }^{16-18}$. In contrast, AR signaling may promote cell proliferation in a subgroup of $\mathrm{ER} \alpha$-negative tumors: AR-positive breast tumors with a molecular apocrine phenotype ${ }^{19-21}$ demonstrated synergy between AR and inhibitors of mitogen-activated protein kinase (MEK) signaling pathways. He et al. showed that AR expression is a favorable prognostic

Table 2. Relationship between androgen receptor expression and Ki-67, histological grade, and tumor-infiltrating lymphocytes in patients with triple negative breast cancer.

\begin{tabular}{|c|c|c|c|c|c|}
\hline \multirow{3}{*}{ Variable } & \multicolumn{4}{|c|}{ Androgen receptor expression } & \multirow{3}{*}{ p-value } \\
\hline & \multicolumn{2}{|c|}{ Positive $(n=11)$} & \multicolumn{2}{|c|}{ Negative $(n=23)$} & \\
\hline & $\mathbf{n}$ & $\%$ & n & $\%$ & \\
\hline \multicolumn{6}{|l|}{ Ki-67 } \\
\hline$<50 \%$ & 8 & 72.7 & 8 & 34.8 & $<0.038$ \\
\hline $51-100 \%$ & 3 & 27.3 & 15 & 65.2 & \\
\hline Mean $\pm S D$ & $43.6 \pm 22.9$ & & $65.0 \pm 20.9$ & & $<0.011$ \\
\hline
\end{tabular}

Histological tumor grade*

\begin{tabular}{c|c|c|c|c|c}
\hline G2 & 2 & 27.3 & 3 & 13.0 & 87.0 \\
\hline G3 & 8 & 72.7 & 20 & & NS \\
\hline TILS & & & & 69.6 & NS \\
\hline$\leq 59 \%$ & 5 & 54.5 & 76.4 & \\
\hline$\geq 60 \%$ & $38.6 \pm 32.1$ & 45.5 & $39.1 \pm 26.4$ & & NS \\
\hline Mean \pm SD & & & 30.4 & \\
\hline
\end{tabular}

*G2: moderately differentiated; G3: poorly differentiated; p-values < 0.05 were considered significant; TILs: tumor-infiltrating lymphocytes; NS: not statistically significant; SD: standard deviation. 
factor of disease-free survival and overall survival in patients with TNBC $(p=0.032)^{22}$. In addition, a recent meta-analysis including 13 studies with 2,826 patients evaluated the prognostic factor value of AR in TNBC and concluded that AR expression was associated with lower risk of disease recurrence ${ }^{23}$.

In agreement with previous studies ${ }^{6,8}$, the present research showed that strong AR expression is associated with older age $(p<0.05)$ when AR-positive cases are subdivided into weakly and strongly positive, with a higher mean age in the strongly AR-positive subgroup (70.8 years). This association has also been reported for other molecular subtypes, for which studies have shown that AR expression was associated with older age and biologically less aggressive tumors ${ }^{16-18,24,25}$.

$\mathrm{Ki}-67$ is a nuclear protein present in proliferating cells in all phases of the cell cycle, except for the G0 (zero) phase. It is detected by monoclonal antibody MIB-1 and is currently the

Table 3. Relationship between intensity of androgen receptor expression and age in patients with triple negative breast cancer.

\begin{tabular}{|c|c|c|c|c|c|}
\hline \multirow{3}{*}{ Variable } & \multicolumn{4}{|c|}{ AR-positive cases } & \multirow{3}{*}{ p-value } \\
\hline & \multicolumn{2}{|c|}{$\begin{array}{c}\text { H-score } \leq 150 \\
(n=6)\end{array}$} & \multicolumn{2}{|c|}{$\begin{array}{c}\text { H-score >150 } \\
(n=5)\end{array}$} & \\
\hline & $n$ & $\%$ & $\mathrm{n}$ & $\%$ & \\
\hline Age (years) & & & & & $<0.015$ \\
\hline $30-34$ & 3 & 50.0 & - & - & \\
\hline $35-39$ & - & - & - & - & \\
\hline $40-44$ & - & - & - & - & \\
\hline $45-49$ & - & - & - & - & \\
\hline $50-54$ & 2 & 33.3 & - & - & \\
\hline $55-59$ & 1 & 16.7 & 1 & 20 & \\
\hline $60-64$ & - & - & 1 & 20 & \\
\hline $65-69$ & - & - & - & - & \\
\hline$>70$ & - & - & 3 & 60 & \\
\hline Mean $\pm S D$ & $42.3 \pm 12.4$ & & $70.8 \pm 11.2$ & & $<0.003$ \\
\hline
\end{tabular}

AR: androgen receptor; SD: standard deviation; p-values < 0.05 were considered significant; H-score $\leq 150$ : 1-150, weakly positive; H-score >150: 151-300, strongly positive.

Table 4. Relationship between intensity of androgen receptor expression and Ki-67, histological grade, and tumor-infiltrating lymphocytes in patients with triple negative breast cancer.

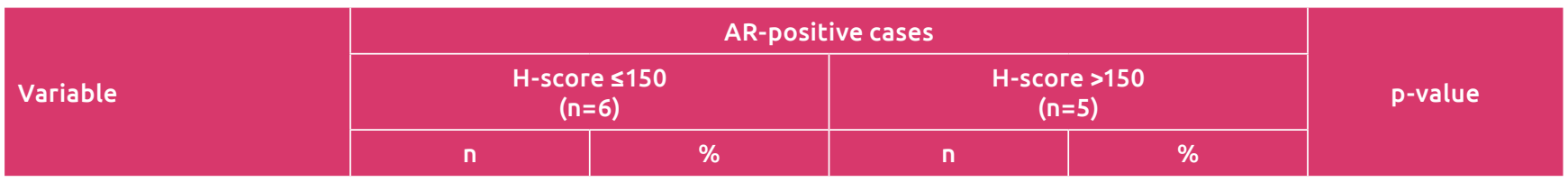

Ki-67

\begin{tabular}{c|c|c|c|c|c}
\hline$<50 \%$ & 4 & 66.7 & 4 & 80 & NS \\
\hline $51-100 \%$ & 2 & 33.3 & 1 & 20 & \\
\hline Mean \pm SD & $50.0 \pm 22.8$ & & $36 \pm 23$ & & NS \\
\hline
\end{tabular}

Histological tumor grade*

\begin{tabular}{c|c|c|c|c|c}
\hline G2 & 1 & 16.3 & 2 & 40 & \multicolumn{3}{|c}{} \\
\hline$G 3$ & 5 & 83.7 & 3 & NS \\
\hline TILS & 3 & 50.0 & 3 & 60 & NS \\
\hline$\leq 59 \%$ & 3 & 50.0 & 2 & 40 & \\
\hline$\geq 60 \%$ & $42.5 \pm 34.0$ & & $34.0 \pm 32.9$ & & NS \\
\hline Mean \pm SD &
\end{tabular}

AR: androgen receptor; H-score $\leq 150$ : 1-150, weakly positive; H-score $>150$ : 151-300, strongly positive; p-values <0.05 were considered significant; SD: standard deviation; *G2: moderately differentiated; G3: poorly differentiated; TILs: tumor-infiltrating lymphocytes; NS: not statistically significant. 
proliferation biomarker of choice ${ }^{26}$. In the present study, TNBC expressing AR had lower proliferation rate than AR-negative tumors $(p<0.05)$. This finding is consistent with the results of recent studies using a $30 \%$ cutoff point ${ }^{6}$ or mean Ki-67 values ${ }^{24}$. In our study, significance was found in the two methods of analysis; however, a higher cutoff point (50\%) was used because $70 \%$ of TNBC cases showed Ki-67 labeling indices $>50 \%$.

The evaluation of histological grade showed no association with AR expression, a finding consistent with previous reports ${ }^{6,24}$. The attempt to subclassify AR expression into strong and weak showed no statistical significance in relation to Ki-67 or histological grade, and a possible explanation for this may be the extremely small number of patients with TNBC expressing AR positivity (n=11).

Evidence suggests that the immune system plays a role in breast cancer and that the presence of TILs is a prognostic factor in this setting ${ }^{27}$. In the present study, however, there was no statistical relationship between AR expression or intensity of AR expression and TILs.

Recently, Pietri et al. demonstrated an overview of AR signaling pathways in different breast cancer subtypes, providing evidence that its oncogenic role is likely to be different in distinct biological and clinical scenarios, including $\mathrm{TNBC}^{28}$. Considering that the main treatment of $\mathrm{TNBC}^{29}$ is chemotherapy, in vitro studies show that AR activation can reduce chemotherapy efficacy in LAR subtype through the AR-mediated transcriptional regulation of pro- and anti-apoptotic genes, suggesting the usefulness of an AR block combined with chemotherapy in this setting ${ }^{30}$.

The present study has some limitations that should be noted. The small sample size and the retrospective nature of medical record review limit the ability to reliably generalize the findings. Despite the advantages of assessing Ki-67, histological grade, and TILs, the evaluation of these parameters reflects an analysis of small tumor areas, through biopsies and surgical specimens, and not of the whole tumor, which can be a limitation due to tumor heterogeneity, combining more or less proliferative areas with various degrees of histological differentiation ${ }^{31}$. Another potential bias is that we analyzed material from both breast biopsies and surgical specimens. However, the sole analysis of surgical specimens would not be feasible, since many patients with TNBC present at initial diagnosis with distant metastases, which precludes curative surgery. Moreover, many patients with TNBC initiate treatment with neoadjuvant chemotherapy (before surgery), preventing the analysis of important pathological parameters, such as histological grade, Ki-67, tumor size, and number of affected axillary lymph nodes. This fact was observed in the present study, since a significant number of patients with TNBC showed complete pathological response to neoadjuvant chemotherapy, i.e., complete tumor remission.

\section{CONCLUSION}

This study showed distinct subgroups of patients with TNBC when tumor expression of AR was observed. Strong AR expression in patients with TNBC was associated with older age and tumors with low proliferation rate, as demonstrated by Ki- 67 assessment, and probably less aggressive behavior from a biological point of view. The identification of subgroups of AR tumor expression in patients with TNBC may be useful in guiding health professionals into a more individualized approach and developing specific therapeutic strategies, in addition to improving monitoring and surveillance. Furthermore, it is known that drugs that bind to AR are hormone therapy drugs with a low incidence of side effects and excellent tolerability, which makes this horizon even more promising considering not only drug efficacy but also treatment effectiveness in AR-positive TNBC patients. Nevertheless, further prospective studies investigating AR expression in a larger number of patients with breast cancer are required to better understand the molecular mechanisms involving AR, which is critical for the development of new therapeutic strategies in breast cancer.

\section{REFERENCES}

1. Brasil. Ministério da Saúde. Instituto Nacional de Câncer José Alencar Gomes da Silva. Estimativa 2016 - Incidência de Câncer no Brasil. 2015 [cited on 2016 Apr 13]. Available from: http://www.inca.gov.br/estimativa/2016/estimativa2016-v11.pdf

2. Curigliano G, Goldhirsch A. The triple-negative subtype: new ideas for the poorest prognosis breast cancer. J Natl Cancer Inst Monogr. 2011;2011(43):108-10.

3. Carey LA, Perou CM, Livasy CA, Dressler LG, Cowan $\mathrm{D}$, Conway $\mathrm{K}$, et al. Race, breast cancer subtypes, and survival in the Carolina Breast Cancer Study. JAMA. 2006;295(21):2492-502.
4. Nielsen TO, Hsu FD, Jensen K, Cheang M, Karaca G, Hu Z, et al. Immunohistochemical and clinical characterization of the basal-like subtype of invasive breast carcinoma. Clin Cancer Res. 2004;10(16):5367-74.

5. Sorlie T, Tibshirani R, Parker J, Hastie T, Marron JS, Nobel A, et al. Repeated observation of breast tumor subtypes in independent gene expression data sets. Proc Natl Acad Sci. 2003;100(14):8418-23.

6. Pistelli M, Caramanti M, Biscotti T, Santinelli A, Pagliacci A, De Lisa M, et al. Androgen receptor expression in early triplenegative breast cancer: clinical significance and prognostic associations. Cancers (Basel). 2014;6(3):1351-62. 
7. Collins LC, Cole KS, Marotti JD, Hu R, Schnitt SJ, Tamimi RM. Androgen receptor expression in breast cancer in relation to molecular phenotype: results from the Nurses' Health Study. Mod Pathol. 2011;24(7):924-31.

8. Park S, Koo J, Park HS, Kim JH, Choi SY, Lee JH, et al. Expression of androgen receptors in primary breast cancer. Ann Oncol. 2010;21(3):488-92.

9. Lakhani S. WHO Classification of Tumours of the Breast. Lyon: International Agency for Research on Cancer; 2012.

10. Atkins D, Reiffen KA, Tegtmeier CL, Winther H, Bonato MS, Storkel S. Immunohistochemical detection of EGFR in paraffin-embedded tumor tissues: variation in staining intensity due to choice of fixative and storage time of tissue sections. J Histochem Cytochem. 2004;52:893-901.

11. Deyarmin B, Kane JL, Valente AL, van Laar R, Gallagher C, Shriver CD, et al. Effect of ASCO/CAP guidelines for determining ER status on molecular subtype. Ann Surg Oncol. 2013;20(1):87-93.

12. Wolff AC, Hammond ME, Hicks DG, Dowsett M, McShane $\mathrm{LM}$, Allison $\mathrm{KH}$, et al. Recommendations for human epidermal growth factor receptor 2 testing in breast cancer: American Society of Clinical Oncology/College of American Pathologists clinical practice guideline update. J Clin Oncol. 2013;31(31):3997-4013.

13. Inwald EC, Klinkhammer-Schalke M, Hofstädter F, Zeman F, Koller M, Gerstenhauer M, et al. Ki-67 is a prognostic parameter in breast cancer patients: results of a large population-based cohort of a cancer registry. Breast Cancer Research and Treatment. 2013;139(2):539-52. doi: 10.1007/ s10549-013-2560-8

14. Adams S, Gray RJ, Demaria S, Goldstein L, Perez EA, Shulman LN, et al. Prognostic value od tumor-infiltrating lymphocytes in triple-negative breast cancers from two phase III randomized adjuvant breast cancer trial: ECOG 2197 and ECOG 1199. J Clin Oncol. 2014;32(27):2959-66.

15. Lakhani S, Ellis I, Schnitt S, Tan PH, Vijver MJV. WHO Classification of Tumours of the Breast. $4^{\mathrm{a}}$ edition. Lyon: IARC Press; 2012

16. Hu R, Dawood S, Holmes MD, Collins LC, Schnitt SJ, Cole K, et al. Androgen receptor expression and breast cancer survival in postmenopausal women. Clin Cancer Res. 2011;17(7):1867-74.

17. Honma N, Horii R, Iwase T, Saji S, Younes M, Ito Y, et al. Clinical importance of androgen receptor in breast cancer patients treated with adjuvant tamoxifen monotherapy. Breast Cancer. 2012;20:323-30

18. Hickey TE, Robinson JL, Carroll JS, Tilley WD. Minireview: The androgen receptor in breast tissues: growth inhibitor, tumor suppressor, oncogene? Mol Endocrinol. 2012;26(8):1252-67.
19. Moore NL, Buchanan G, Harris JM, Selth LA, Bianco-Miotto T, Hanson AR, et al. An androgen receptor mutation in the MDA-MB-453 cell line model of molecular apocrine breast cancer compromises receptor activity. Endocr Relat Cancer. 2012;19(4):599-613.

20. Iggo RD. New insights into the role of androgen and estrogen receptors in molecular apocrine breast tumours. Breast Cancer Res. 2011;13(6):318.

21. Naderi A, Chia KM, Liu J. Synergy between inhibitors of androgen receptor and MEK has therapeutic implications in estrogen receptor-negative breast cancer. Breast Cancer Res. 2011;13(2):R36.

22. He J, Peng R, Yuan Z, Wang S, Peng J, Lin G, et al. Prognostic value of androgen receptor expression in operable triplenegative breast cancer: a retrospective analysis based on a tissue microarray. Med Oncol. 2012;29(2):406-10.

23. Wang C, Pan B, Zhu H, Zhou Y, Mao F, Lin Y, et al. Prognostic value of androgen receptor in triple negative breast cancer: a meta-analysis. Oncotarget. 2016;7(29):46482-91.

24. Qi JP, Yang YL, Zhu H, Wang J, Jia Y, Liu N, et al. Expression of the androgen receptor and its correlation with molecular subtypes in 980 Chinese breast cancer patients. Breast Cancer (Auckl). 2012;6:1-8.

25. Jiang HS, Kuang XY, Sun WL, Xu Y, Zheng YZ, Liu YR, et al. Androgen receptor expression predicts different clinical outcomes for breast cancer patients stratified by hormone receptor status. Oncotarget. 2016;7(27):41285-93.

26. Gerdes J, Schwab U, Lemke H, Stein H. Production of a mouse monoclonal antibody reactive with a human nuclear antigen associated with cell proliferation. Int J Cancer. 1983;31(1):13-20.

27. Adams S, Gray RJ, Demaria S, Goldstein L, Perez EA, Shulman $\mathrm{LN}$, et al. Prognostic value of tumor-infiltrating lymphocytes in triple-negative breast cancers from two phase III randomized adjuvant breast cancer trials: ECOG 2197 and ECOG 1199. J Clin Oncol. 2014;32(27):2959-66.

28. Pietri E, Conteduca V, Andreis D, Massa I, Melegari E, Sarti S, et al. Androgen receptor signaling pathways as a target for breast cancer treatment. Endocr Relat Cancer. 2016;23(10):R485-98.

29. Bianchini G, Balko JM, Mayer IA, Sanders ME, Gianni L. Triple-negative breast cancer: challenges and opportunities of a heterogeneous disease. Nat Rev Clin Oncol. 2016 May 17;13(11)674-90.

30. Kach J, Conzen SD, Szmulewitz RZ. Targeting the glucocorticoid receptor in breast and prostate cancers. Sci Transl Med. 2015;7(305):305ps19.

31. Romero Q, Bendahl PO, Ferno M, Grabau D, Borgquist S. A novel model for Ki67 assessment in breast cancer. Diagn Pathol. 2014:9:118 